\title{
Carbon Dioxide Enrichment Enhances Growth and Flavonoid Content of Two Scutellaria species
}

\author{
Gary W. Stutte ${ }^{1}$ and Ignacio Eraso \\ Dynamac Corporation, Mail Code DYN-3, Kennedy Space Center, FL 32899
}

\author{
Agnes M. Rimando \\ U.S. Department of Agriculture-Agricultural Research Service, National Center for Natural Products \\ Research, University, MS 38677
}

\begin{abstract}
AdDitional INDEX words. Scutellaria barbata, Scutellaria lateriflora, scullcap, medicinal plants, baicalin, baicalein, wogonin, apigenin, chrysin, scutellarin

ABstract. Scutellaria L. is a genus of herbaceous perennials of the Lamianaceae that includes several species with medicinal properties. The medicinal species of $S$ cutellaria are rich in physiologically active flavonoids with a range of pharmacological activity. Experiments were conducted to determine the feasibility of increasing the growth rate and flavonoid content of Scutellaria barbata D. Don and Scutellaria lateriflora $\mathrm{L}$. with $\mathrm{CO}_{2}$ enrichment in a controlled environment. Both species showed an increased growth rate and total biomass in response to $\mathrm{CO}_{2}$ enrichment from 400 to $1200 \mathrm{\mu mol} \cdot \mathrm{mol}^{-1} \mathrm{CO}_{2}$, and time to flowering was accelerated by 7 to 10 days. The bioactive flavonoids scutellarein, baicalin, apigenin, baicalein, and wogonin were detected in vegetative tissue of $S$. barbata. Total flavonoid content increased $50 \%$ with enrichment of $\mathrm{CO}_{2}$ to 1200 and $81 \%$ with $3000 \mu \mathrm{mol} \cdot \mathrm{mol}^{-1}$. Scutellarein, baicalin, and apigenin concentrations increased with increasing $\mathrm{CO}_{2}$, whereas baicalein and wogonin did not. The flavonoids baicalin, baicalein, wogonin, and chrysin were detected in the vegetative tissue of $S$. lateriflora. The total concentration of the bioactive flavonoids measured in the vegetative tissue of $S$. lateriflora was much higher than $S$. barbata under ambient $\mathrm{CO}_{2}$ conditions (1144 vs. $249 \mu \mathrm{g} \cdot \mathrm{g}^{-1}$ dry weight). The total content of the measured bioactive flavonoids increased 2.4 times with enrichment to $1200 \mu \mathrm{mol} \cdot \mathrm{mol}^{-1} \mathrm{CO}_{2}$, and 5.9 times with enrichment to $3000 \mu \mathrm{mol} \cdot \mathrm{mol}^{-1} \mathrm{CO}_{2}$. These results indicate that the yield and pharmaceutical quality of Scutellaria species can be enhanced with controlled environment production and $\mathrm{CO}_{2}$ enrichment.
\end{abstract}

Scutellaria is a genus of herbaceous perennials of the Lamiaceae that includes several species with purported medicinal properties (Awad et al., 2003; Bonham et al., 2005; Joshee et al., 2002; Sato et al., 2000). Many Scutellaria species are rich in physiologically active flavonoids that have a wide spectrum of pharmacological activity. The medicinally significant part of the plant is species dependent.

Leaf extracts of Scutellaria barbata, also known as "Ban Zhi Lian," indigenous to southern China, have been used in traditional Chinese medicine to treat liver and digestive disorders and cancers (Molony and Molony, 1998). Recent research has shown extracts of $S$. barbata to be limiting to the growth of cell lines associated with lung, liver, prostate, and brain tumors (Yin et al., 2004).

Scutellaria lateriflora is indigenous to, and widely distributed across, North America [U.S. Department of Agriculture (USDA), 2008], and extracts and infusions of the leaves/stems were widely used in Native American medicinal traditions. $S$. lateriflora is commonly known as skullcap, american skullcap, blue skullcap, and mad dog skullcap (Awad et al., 2003; Joshee et al., 2002). There is increasing demand for S. lateriflora as a complementary and alternative medical treatment for anxiety (Greenfield and Davis, 2004). Extracts of S. lateriflora and the isolated flavonoids from the extracts have been shown to have antioxidant, anticancer, and antiviral properties (Awad et al., 2003).

Received for publication 4 Feb. 2008. Accepted for publication 28 May 2008. We thank FÁS (Foras Áiseanna Saothair, Ireland) for their Science Challenge Program Internship support of Karen Downing (Limerick Institute of Technology, Limerick, Ireland) who provided horticultural and technical support.

${ }^{1}$ Corresponding author. E-mail: gary.w.stutte@nasa.gov.
Scutellaria baicalensis Georgi is the most widely used and studied medicinal species of the genus. The root/rhizome of $S$. baicalensis has been used for thousand of years in the traditional Chinese medicine preparation "Huang Qin" for nervousness, high blood pressure, and respiratory disorders (Molony and Molony, 1998). The root preparations are also used in traditional medical systems of Nepal, Japan, and Korea. The leaf tissue is not typically used in medicinal preparations.

Despite the long-term and widespread use of these medicinal plants, there is limited information on the horticultural production of Scutellaria species. Joshee et al. (2002) reported the results of growth studies of several species of Scutellaria in the field, Thomas and Schrock (2004) included Scutellaria species in a winterhardiness trial of several midwestern United States perennial species, and Wills and Stuart (2004) gave an overview of Scutellaria production in Australia. Greenfield and Davis (2004) established general guidelines for field production of S. lateriflora in North Carolina and Janke et al. (2005) gave production recommendations for small farmers in Kansas. Horticultural production guidelines for Scutellaria galericulata L. and S. baicalensis have been prepared by Saskatchewan Agriculture and Food (Porter, 2005).

The primary source of material for commerce is from wildcrafting, the practice of harvesting from the native environment. The collection of plant material from the field results in significant variation in the growth, composition, and quality of plant material used in herbal preparations. This is a serious issue that limits the quality of tests of clinical efficacy (Mars and Bent, 1999; Wolsko et al., 2005), has high potential for accidental or intentional adulteration (Furbee et al., 2006), and 
produces variable composition of bioactive flavonoids (Smolinski, 2005; Wolsko et al., 2005).

Controlled environment (CE) production of plants eliminates variation associated with climate, soil, and nutrition (Goins et al., 2003; Rosen et al., 2005; Stutte, 2006), allows standardization of production and harvest protocols (Radovich et al., 2005), minimizes contamination of samples by weeds, insects, and foreign matter (Gruda, 2005), and increases uniformity of secondary metabolite production (Charron and Sams, 2004; Richards et al., 2004). As such, CE has the potential to increase the productivity and quality of medicinal plants (Pagliarulo et al., 2003; Stutte, 2006).

Stutte et al. (2007) conducted a number of experiments to determine the feasibility of growing Scutellaria species in $\mathrm{CE}$ and described the light and temperature requirements for germination and early establishment of S. barbata, S. baicalensis, and S. lateriflora. Stutte et al. (2007) also reported that $S$. lateriflora and $S$. barbata had increased growth rate and reduced time to bloom by 7 to $10 \mathrm{~d}$ when grown in $\mathrm{CE}$ with $\mathrm{CO}_{2}$ enrichment. They concluded that the long growth cycle (2 years or more) to produce a marketable rhizome of $S$. baicalensis did not lend itself to $\mathrm{CE}$ production. However, CE production was promising for $S$. barbata and $S$. lateriflora where the leaf and shoot were the desired products of commerce.

Atmospheric enrichment of greenhouses to $1000 \mu \mathrm{mol} \cdot \mathrm{mol}^{-1}$ $\mathrm{CO}_{2}$ or more is a well-established practice for a number of high-value horticultural crops due to its positive effects on photosynthetic rate, total biomass production, and time to horticultural maturity (Hinkleton, 1988; Porter and Grodzinski, 1985). There are also many reports that $\mathrm{CO}_{2}$ enrichment increases the production of secondary metabolites (Estiarte et al., 1999; Veteli et al., 2002) and antioxidant activity (Wang et al., 2003). Malikov and Yuldashev (2002) reviewed distribution and properties of phenolic compounds detected in Scutellaria species. Of the 208 substances that had been isolated and identified from 65 Scutellaria species, over $80 \%$ were flavonoids. Increased concentration of flavonoids through $\mathrm{CO}_{2}$ enrichment has the potential to enhance the production and quality of medicinal plants such as Scutellaria.

The objective of the following experiments was to determine the effects of $\mathrm{CO}_{2}$ enrichment on the growth of $S$. lateriflora and $S$. barbata and on production of six bioactive flavonoids, apigenin (5,7,4'-trihydroxyflavone), baicalin (baicalein-7-Oglucuronide), baicalein (5,6,7-trihydroxyflavone), chrysin (5,7-dihydroxyflavone), scutellarein (5,6,7,4'-tetrahydroxyflavone), and wogonin (5,7-dihydroxy-8-methoxyflavone) that have been reported to have anticancer and antiviral properties (reviewed in Cole et al., 2007; Joshee et al., 2002).

\section{Materials and Methods}

Plant Material. Seeds of S. lateriflora and S. barbata were obtained from Johnny's Selected Seeds (Winslow, ME) or Horizon Herbs (Williams, OR) and were stored desiccated at $4{ }^{\circ} \mathrm{C}$ until use.

CE CHAMbers (CEC). A large step-in CEC (EGC M-36; Environmental Growth Chambers, Chagrin Falls, OH) was used to provide a consistent light quality, light intensity, and photoperiod to six smaller plant growth chambers that contained six plants each. The plant growth chambers had been originally designed as volatile organic compound analysis chambers (Stutte et al., 2005) and had high-fidelity control of relative humidity $(\mathrm{RH})$, temperature, and $\mathrm{CO}_{2}$ concentration. Photosynthetic photon flux $(P P F)$ was provided by T8 triphosphor fluorescent (TPF) lamps (Sylvania FP541/841/HO; Osram Sylvania, Westfield, IN) with dimmable ballasts. Photoperiod and air temperature of the large CEC were controlled using integrated control, monitoring, and data management system software (Dynamac Corp., Rockville, MD).

The smaller plant growth chambers were designed to allow nutrient solution uptake to be monitored for the six individual plants as well (Fig. 1). Each nutrient delivery system consists of a calibrated nutrient reservoir, replenishment solution, nutrient containment chamber, siphon assembly, and the individual plant chamber. The interaction of nutrient solution level and root matrix is used to establish and maintain the desired moisture content conditions (Stutte et al., 2005).

Each individual plant growth chamber is constructed of 0.6$\mathrm{cm}$ polycarbonate for the walls and bottom, and 0.6- $\mathrm{cm}$ acrylic for the top. A cross-flow fan placed in the bottom underneath a raised floor in the chamber forces air across a series of eight ceramic porous tubes which provide $\mathrm{RH}$ control, and over a heating strip that provides temperature control.

$\mathrm{CO}_{2}$ is delivered to the individual chambers via the facility's $\mathrm{CO}_{2}$ supply, which has been passed through silica, activated carbon, and Purafil ${ }^{\mathrm{TM}}$ (Purafil, Doraville, GA) filters before being mixed with filtered breathing air. This design provides removal of ethylene and volatile organic compounds that affect plant growth (Eraso et al., 2003; Stutte, 1999; Stutte et al., 2006).

The environmental conditions in the chamber were monitored with a $\mathrm{CO}_{2}$ sensor (GMT222; Viasala, Woburn, MA) in the back of the chamber and with a telescoping rod containing RH (H1H 3605; Honeywell, Golden Valley, MN), temperature (Type J thermocouple), and PPF (Quantum sensor; LI-COR, Lincoln, NE) sensors, and data were stored at 5-min intervals in the control, monitoring, and data management system software database at Kennedy Space Center, FL. The environmental data were archived under the experiment code names of SC0702a (Rep 1) or SC0902b (Rep 2). The experiments will be referred to as Rep 1 or Rep 2 for the remainder of the article.

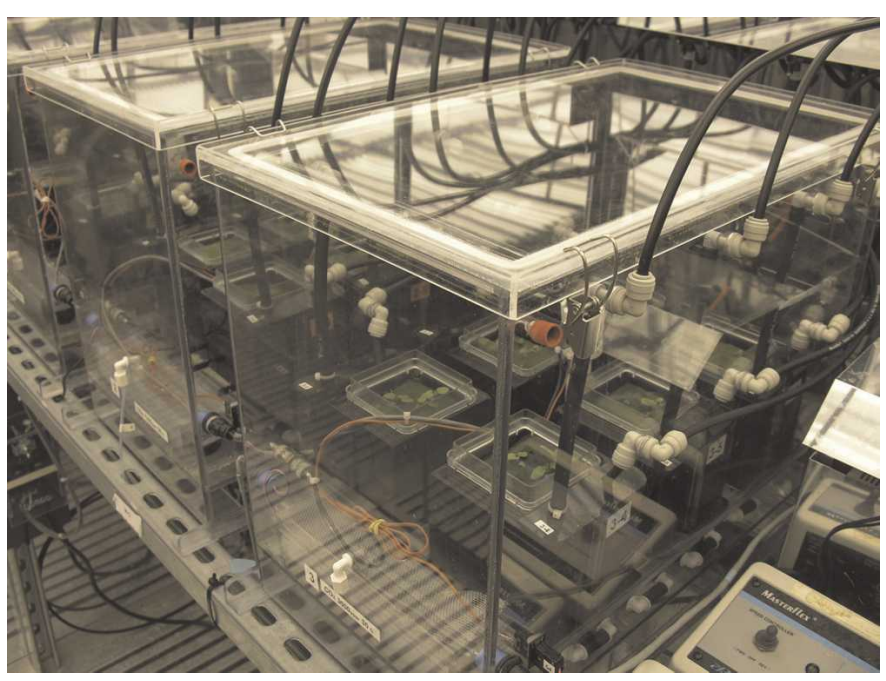

Fig. 1. Scutellaria were grown in specially constructed chambers to provide temperature, relative humidity, and $\mathrm{CO}_{2}$ to six individual plants. Photoperiod and light intensity were controlled in a controlled environment chamber. 
EFFeCtS OF ELEVATEd $\mathrm{CO}_{2}$ ON BIOMASS PRODUCTION. Seeds of $S$. barbata and $S$. lateriflora were selected for uniformity and presoaked in deionized water for $72 \mathrm{~h}$ at $4{ }^{\circ} \mathrm{C}$ in the dark. This treatment had been found to increase the uniformity and percentage of germination (Stutte et al., 2007). After presoaking, six seeds were planted in $6 \times 6 \times 7.5-\mathrm{cm}$ rockwool blocks (Grodan $^{\mathrm{TM}}$, Hedehusene, Denmark) that had been prewetted with $1 \times$ Hoagland solution (Hoagland and Arnon, 1950). The rockwool blocks were placed in the nutrient delivery systems of the plant growth chambers. There were six plants in each chamber and the experiment was repeated twice.

Three of the smaller plant growth chambers were planted with $S$. barbata and three with $S$. lateriflora. The environmental set points for $S$. barbata were $30{ }^{\circ} \mathrm{C}(30.0 \pm 0.61 \mathrm{sD}), 75 \% \mathrm{RH}$ $(73.3 \pm 3.6 \mathrm{sD})$, and $300(318 \pm 26.3 \mathrm{sD}) \mu \mathrm{mol} \cdot \mathrm{m}^{-2} \cdot \mathrm{s}^{-1} P P F$ with a 16-h light/8-h dark photoperiod with TPF lamps. $\mathrm{CO}_{2}$ concentrations of $400(467 \pm 140 \mathrm{SD}), 1200(1991 \pm 61 \mathrm{SD})$, or 3000 $(2847 \pm 298 \mathrm{sD}) \mu \mathrm{mol} \cdot \mathrm{mol}^{-1} \mathrm{CO}_{2}$ were maintained in the chambers during the light cycle for the 49-d duration of the experiment. There was no active $\mathrm{CO}_{2}$ control during the dark cycle.

The environmental set points for S. lateriflora were $26{ }^{\circ} \mathrm{C}$ $(25.8 \pm 0.54 \mathrm{sD}), 75 \% \mathrm{RH}(74.2 \pm 4.1 \mathrm{SD})$, and $300(294 \pm 19 \mathrm{sD})$ $\mu \mathrm{mol} \cdot \mathrm{m}^{-2} \cdot \mathrm{s}^{-1} P P F$ with a $16-\mathrm{h}$ light $/ 8$-h dark photoperiod with TPF lamps. $\mathrm{CO}_{2}$ concentrations of $400(521 \pm 218 \mathrm{SD}), 1200$ $(1213 \pm 424 \mathrm{sD})$, or $3000(2826 \pm 336 \mathrm{sD}) \mu \mathrm{mol} \cdot \mathrm{mol}^{-1} \mathrm{CO}_{2}$ were maintained in the chambers during the light cycle for the 49-d duration of the experiment. There was no active $\mathrm{CO}_{2}$ control during the dark cycle.

Growth ANALYSIS. Plants were harvested at 35 or $49 \mathrm{~d}$ after planting (DAP), and plant height, node number, leaf area, and fresh weight were determined. Plants were then dried for 48 to $72 \mathrm{~h}$ at $70{ }^{\circ} \mathrm{C}$ and dry weight (DM) was determined. Dried samples were then ground through a 40 -mesh screen with a Wiley Mill before analysis. In Rep 1, the total top mass was harvested for biometric data, dried, and analyzed for flavonoid content. In Rep 2, the top tissue was separated into leaf and stem tissue before collecting biometric data.

EXTRACTION OF SCUTELLARIA SAMPLES. Extraction for dried leaves or stems was performed using an Accelerated Solvent Extraction (ASE ${ }^{\circledR}$; Dionex Corp., Sunnyvale, CA) apparatus at the USDA-Agricultural Research Service (ARS), Natural Products Utilization Research Unit (NPURU). About $1 \mathrm{~g}$ of dried, powdered sample was mixed with $1 \mathrm{~g}$ of purified sand (Fisher Scientific, Pittsburgh, PA) and was loaded in the extraction cartridge. Purified sand was added to fully pack the extraction cartridge. Extraction was carried out with the following parameters: heat, $5 \mathrm{~min}$; static, $10 \mathrm{~min}$; flush volume, $100 \mathrm{~mL}$; purge, $90 \mathrm{~s}$; pressure, $6.9 \mathrm{MPa}$; temperature, $40{ }^{\circ} \mathrm{C}$; extraction solvent, methanol: water (80:20), four cycles. The extracts were concentrated under vacuum using a Savant SpeedVac (model SPD121P; Savant Instruments, Holbrook, NY). Dried extracts were weighed and an aliquot was dissolved in $0.5 \% \mathrm{HCl}$-methanol and analyzed by high-pressure liquid chromatography (HPLC) for their content of flavonoids.

HPLC ANALYSIS OF EXTRACTS. Extracts were analyzed on a HPLC (Hewlett-Packard 1050; Agilent Technologies, Santa Clara, CA) using a $5-\mu \mathrm{m}, 250 \times 5.6-\mathrm{mm}$ column (Inertsil ODS2; Alltech Associates, Deerfield, IL) and monitored for their content of apigenin, baicalin, baicalein, chrysin, scutellarein, and wogonin at $1270 \mathrm{~nm}$. The mobile phase consisted of $0.005 \%$ phosphoric acid (solvent A) and acetonitrile (solvent B) in a gradient elution starting from $36 \%$ to $100 \%$ B over a $37-$ min run at a flow rate of $1 \mathrm{~mL} \cdot \mathrm{min}^{-1}$. The flavonoids were quantified from a calibration curve of the standards (purchased from SigmaAldrich, St. Louis) with 6-hydroxyflavone as internal standard. A typical HPLC chromatograph of the standards and extract is shown in Fig. 2.

STATISTICAL ANALYsis. Data were analyzed using analysis of variance and mean separation between $\mathrm{CO}_{2}$ treatments using Tukey's test at $P \leq 0.05$ with GraphPad Prism statistical software (GraphPad Software, San Diego).

\section{Results}

$\mathrm{CO}_{2}$ had a significant effect on the growth and development of $S$. barbata (Fig. 3) and S. lateriflora (Fig. 4). Increasing the concentration of $\mathrm{CO}_{2}$ from 400 to $1200 \mu \mathrm{mol} \cdot \mathrm{mol}^{-1}$ had no significant effect on plant height or node number of S. barbata (Table 1). Increasing $\mathrm{CO}_{2}$ to $1200 \mu \mathrm{mol} \cdot \mathrm{mol}^{-1}$ resulted in a $24 \%$ increase in total leaf area, a $36 \%$ increase in fresh weight, and a $54 \%$ increase in top DM. There was no detrimental effect of increasing $\mathrm{CO}_{2}$ to $3000 \mu \mathrm{mol} \cdot \mathrm{mol}^{-1}$ (Table 1).

Similarly, increasing the concentration of $\mathrm{CO}_{2}$ from 400 to $1200 \mu \mathrm{mol} \cdot \mathrm{mol}^{-1}$ had no significant effect on plant height of $S$. lateriflora (Table 1), but did result in a $31 \%$ increase in node number, $62 \%$ increase in top fresh weight, and $44 \%$ increase in
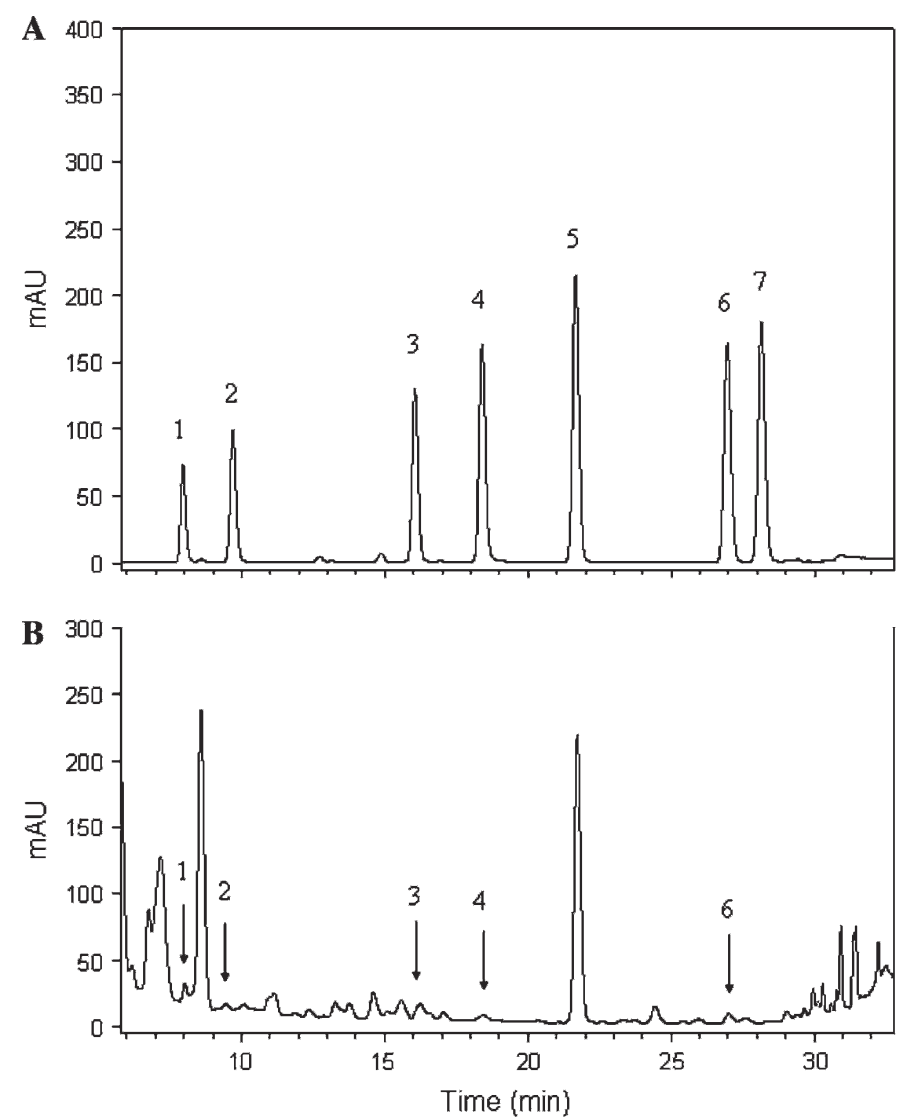

Fig. 2. High-pressure liquid chromatography trace of (A) flavonoid standards: (1) scutellarein, $7.9 \mathrm{~min}$; (2) baicalin, $9.7 \mathrm{~min}$; (3) apigenin, $16.0 \mathrm{~min}$; (4) baicalein, $18.3 \mathrm{~min}$; (5) 6-hydroxyflavone used as internal standard, $21.7 \mathrm{~min}$; (6) wogonin, $27.0 \mathrm{~min}$; and (7) chrysin, $28.1 \mathrm{~min}$; (B) extract from Scutellaria barbata sample treated with $400 \mu \mathrm{mol} \cdot \mathrm{mol}^{-1} \mathrm{CO}_{2}$. Chromatograms are from absorbance at $\lambda 270 \mathrm{~nm}$. 


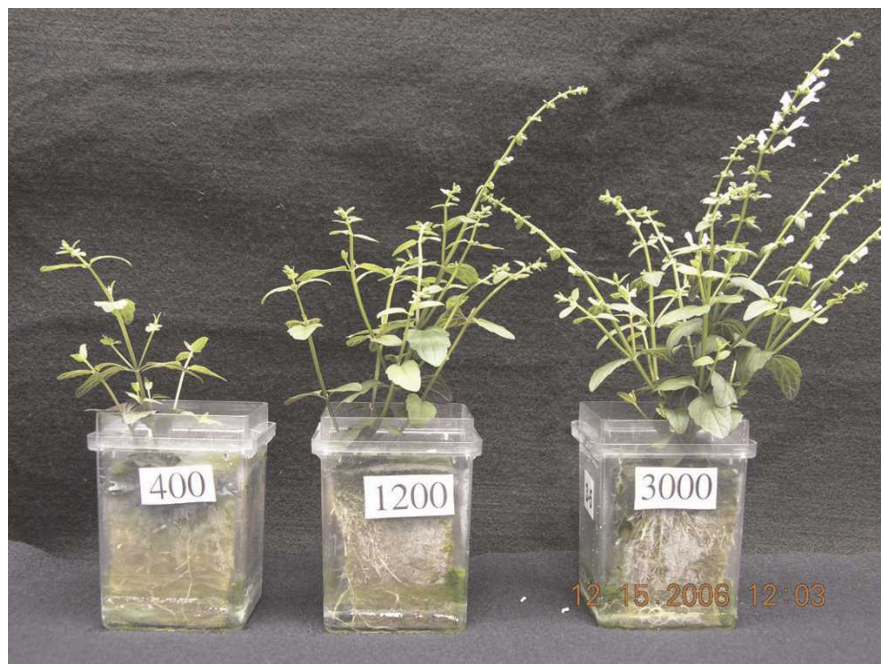

Fig. 3. Effect of 400 (left), 1200 (center), and 3000 (right) $\mu \mathrm{mol} \cdot \mathrm{mol}^{-1} \mathrm{CO}_{2}$ on growth of Scutellaria barbata at $49 \mathrm{~d}$ after planting.

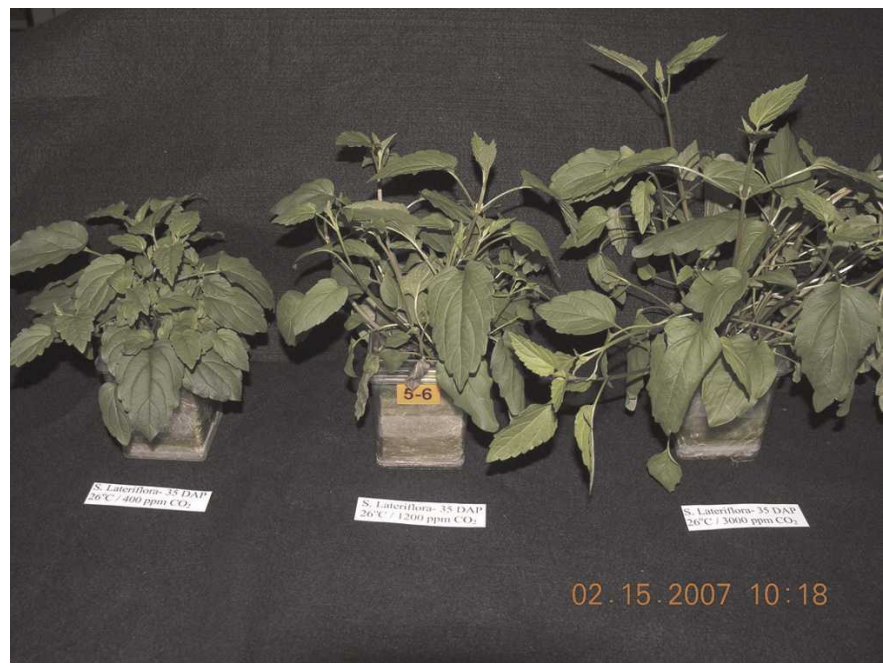

Fig. 4. Effect of 400 (left), 1200 (center), and 3000 (right) $\mu \mathrm{mol} \cdot \mathrm{mol}^{-1} \mathrm{CO}_{2}$ on growth of Scutellaria lateriflora at $35 \mathrm{~d}$ after planting.

Table 1. Effect of carbon dioxide concentration on growth and biomass production of Scutellaria barbata and S. lateriflora at $49 \mathrm{~d}$ after planting.

\begin{tabular}{|c|c|c|c|c|c|}
\hline $\begin{array}{l}\mathrm{CO}_{2} \\
\left(\mu \mathrm{mol} \cdot \mathrm{mol}^{-1}\right)\end{array}$ & $\begin{array}{l}\text { Plant } \\
\text { ht }(\mathrm{cm})\end{array}$ & $\begin{array}{c}\text { Nodes } \\
\text { (no.) }\end{array}$ & $\begin{array}{c}\text { Leaf area } \\
\left(\mathrm{cm}^{2}\right)\end{array}$ & $\begin{array}{c}\text { Shoot fresh } \\
\text { wt (g) }\end{array}$ & $\begin{array}{c}\text { Shoot } \\
\text { dry wt }(\mathrm{g})\end{array}$ \\
\hline \multicolumn{6}{|c|}{ S. barbata } \\
\hline 400 & $26.6 \mathrm{a}^{\mathrm{z}}$ & $15.3 \mathrm{a}$ & $253 \mathrm{a}$ & $8.5 \mathrm{a}$ & $1.83 \mathrm{a}$ \\
\hline 1200 & $29.2 \mathrm{a}$ & $18.0 \mathrm{a}$ & $316 \mathrm{~b}$ & $11.6 \mathrm{~b}$ & $2.82 \mathrm{~b}$ \\
\hline 3000 & $26.9 \mathrm{a}$ & $17.3 \mathrm{a}$ & $317 \mathrm{~b}$ & $10.4 \mathrm{~b}$ & $2.88 \mathrm{~b}$ \\
\hline \multicolumn{6}{|c|}{ S. lateriflora } \\
\hline 400 & $21.7 \mathrm{a}$ & $9.3 \mathrm{a}$ & $630 \mathrm{a}$ & $18.5 \mathrm{a}$ & $3.09 \mathrm{a}$ \\
\hline 1200 & $25.5 \mathrm{a}$ & $12.2 \mathrm{~b}$ & $639 a$ & $30.0 \mathrm{~b}$ & $4.44 \mathrm{~b}$ \\
\hline 3000 & $26.7 \mathrm{a}$ & $11.7 \mathrm{~b}$ & $1009 \mathrm{~b}$ & $41.1 \mathrm{c}$ & $5.24 \mathrm{c}$ \\
\hline
\end{tabular}

${ }^{\mathrm{z}}$ Mean separation within columns within columns and species at $P \leq$ 0.05 using Tukey's mean separation.

total DM. There was no statistically significant effect on total leaf area (Table 1). Further enrichment to $3000 \mu \mathrm{mol} \cdot \mathrm{mol}^{-1} \mathrm{CO}_{2}$ had no additional effect on plant height or node number, but did produce a $58 \%$ increase in leaf area, $37 \%$ increase in fresh weight, and $18 \%$ increase in top DM over the $1200 \mu \mathrm{mol} \cdot \mathrm{mol}^{-1}$ $\mathrm{CO}_{2}$ treatment.

The effects of $\mathrm{CO}_{2}$ enrichment on biomass partitioning between leaf and stem tissue at two stages of development was looked at during Rep 2 (Table 2). The harvest times corresponded to flowering (35 DAP) and seed drop (49 DAP). The results on growth were similar to those obtained in Rep 1, except that the 3000 treatment resulted in an increase in plant height at 35 DAP, but not at 49 DAP.

The flavonoid content of the leaf and stem tissue was determined separately in tissue from Rep 2 to see if there was a difference in partitioning between leaf and stem tissue. The flavonoid content was not statistically different between the leaf and stem tissue at any $\mathrm{CO}_{2}$ concentration (data not shown). The concentration of the combined leaf/stem analysis is discussed in the remainder of the article.

Increasing the $\mathrm{CO}_{2}$ concentration from ambient (400 $\mu \mathrm{mol} \cdot \mathrm{mol}^{-1}$ ) in S. lateriflora resulted in the partitioning of biomass toward the stem tissue, with $31.6 \%$ of shoot DM in stem at ambient $\mathrm{CO}_{2}$ and $36.1 \%$ and $38.8 \%$ in the 1200 and $3000 \mu \mathrm{mol} \cdot \mathrm{mol}^{-1}$ treatments, respectively. There was increase in leaf mass per area as well, with increases of $9.3 \%$ at 1200 and $15.1 \%$ at $3000 \mu \mathrm{mol} \cdot \mathrm{mol}^{-1} \mathrm{CO}_{2}$ (Table 3 ).

Increasing the $\mathrm{CO}_{2}$ concentration affected the concentration of flavonoids in the vegetative tissue of $S$. barbata. The combined concentration of the six flavonoids measured increased by $48 \%$ at 1200 and $81 \%$ at $3000 \mu \mathrm{mol} \cdot \mathrm{mol}^{-1} \mathrm{CO}_{2}$ (Fig. 5). Scutellarein was the predominant flavonoid in $S$. barbata, followed by baicalin, apigenin, baicalein, and wogonin. Chrysin was not detected in the dried vegetative tissue. $\mathrm{CO}_{2}$ enrichment had no effect on baicalein or wogonin concentration. Increasing the $\mathrm{CO}_{2}$ from 400 to $1200 \mu \mathrm{mol} \cdot \mathrm{mol}^{-1}$ resulted in a $78 \%$ increase in scutellarein, a $55 \%$ increase in baicalin, and a $39 \%$ increase in apigenin concentration in the dried tissue. Increasing the concentration to $3000 \mu \mathrm{mol} \cdot \mathrm{mol}^{-1} \mathrm{CO}_{2}$ had no additional effect on flavonoid concentration.

Total flavonoid concentration of S. lateriflora was significantly higher than $S$. barbata (1144 vs. $\left.249 \mu \mathrm{g} \cdot \mathrm{g}^{-1} \mathrm{DM}\right)$ and had a more pronounced response to $\mathrm{CO}_{2}$ enrichment. The total flavonoid content increased by over $2.4 \times$ at 1200 and $4.9 \times$ at $3000 \mu \mathrm{mol} \cdot \mathrm{mol}^{-1} \mathrm{CO}_{2}$ (Fig. 6). Under ambient $\mathrm{CO}_{2}$ conditions, baicalin and baicalein were the dominant flavonoids, followed by wogonin and chrysin. Scutellarein and apigenin were not detected in the leaf tissue. The four flavonoids that were monitored all increased in response to $\mathrm{CO}_{2}$ enrichment. Baicalin concentration increased 2.8-fold at $1200 \mu \mathrm{mol} \cdot \mathrm{mol}^{-1}$ $\mathrm{CO}_{2}$ and 4.7-fold at $3000 \mu \mathrm{mol} \cdot \mathrm{mol}^{-1} \mathrm{CO}_{2}$. Baicalein, wogonin, and chrysin increased in a similar manner.

The effects of $\mathrm{CO}_{2}$ enrichment on plant growth and flavonoid content produced a compounding effect at the whole plant level, resulting in nearly a doubling of the concentration of bioactive flavonoid content in S. barbata (Fig. 7). The total content of flavonoids measured increased from $0.57 \mathrm{mg} / \mathrm{plant}$ at $400 \mu \mathrm{mol} \cdot \mathrm{mol}^{-1} \mathrm{CO}_{2}$ to $0.98 \mathrm{mg} / \mathrm{plant}$ at $1200 \mu \mathrm{mol} \cdot \mathrm{mol}^{-1} \mathrm{CO}_{2}$ and $1.3 \mathrm{mg} / \mathrm{plant}$ at $3000 \mu \mathrm{mol} \cdot \mathrm{mol}^{-1} \mathrm{CO}_{2}$. The increases were due to total plant content of scutellarein, baicalin, and apigenin. There were no significant differences in total plant concentration of baicalein or wogonin with $\mathrm{CO}_{2}$ enrichment.

The compounding effects were significantly stronger in $S$. lateriflora due to the responsiveness of growth and flavonoid production up to $3000 \mu \mathrm{mol} \cdot \mathrm{mol}^{-1} \mathrm{CO}_{2}$. There was a 4.2 -fold increase in total flavonoid content when enriching from 400 to 
Table 2. Effect of carbon dioxide concentration on growth and biomass partitioning of Scutellaria barbata at 35 and $49 \mathrm{~d}$ after planting.

\begin{tabular}{|c|c|c|c|c|c|c|c|}
\hline $\begin{array}{l}\mathrm{CO}_{2} \\
\left(\mu \mathrm{mol} \cdot \mathrm{mol}^{-1)}\right.\end{array}$ & $\begin{array}{l}\text { Plant } \\
\text { ht }(\mathrm{cm})\end{array}$ & $\begin{array}{c}\text { Nodes } \\
\text { (no.) }\end{array}$ & $\begin{array}{l}\text { Leaf area } \\
\left(\mathrm{cm}^{2}\right)\end{array}$ & $\begin{array}{c}\text { Stem dry } \\
\text { wt }(\mathrm{g})\end{array}$ & $\begin{array}{c}\text { Leaf dry } \\
\text { wt (g) }\end{array}$ & $\begin{array}{c}\text { Total dry } \\
\text { wt (g) }\end{array}$ & $\begin{array}{c}\text { Leaf mass per area } \\
\left(\mathrm{kg} \cdot \mathrm{m}^{-2}\right)\end{array}$ \\
\hline 400 & $21.2 \mathrm{a}^{\mathrm{z}}$ & $13.5 \mathrm{a}$ & $84.4 \mathrm{a}$ & $0.250 \mathrm{a}$ & $0.314 \mathrm{a}$ & $0.564 \mathrm{a}$ & $0.038 \mathrm{a}$ \\
\hline 3000 & $23.7 \mathrm{a}$ & $15.0 \mathrm{a}$ & $60.2 \mathrm{a}$ & $0.196 \mathrm{a}$ & $0.402 \mathrm{a}$ & $0.597 \mathrm{a}$ & $0.066 \mathrm{c}$ \\
\hline & \multicolumn{7}{|c|}{$49 \mathrm{~d}$ after planting } \\
\hline 400 & $24.6 \mathrm{a}$ & $16.0 \mathrm{a}$ & $132.7 \mathrm{a}$ & $0.596 \mathrm{a}$ & $0.961 \mathrm{a}$ & $1.577 \mathrm{a}$ & $0.072 \mathrm{a}$ \\
\hline 3000 & $28.2 \mathrm{~b}$ & $16.5 \mathrm{a}$ & $131.0 \mathrm{a}$ & $0.747 \mathrm{c}$ & $1.251 \mathrm{~b}$ & $1.997 \mathrm{~b}$ & $0.095 \mathrm{~b}$ \\
\hline
\end{tabular}

${ }^{\mathrm{z}}$ Mean separation within columns within columns and species at $P \leq 0.05$ using Tukey's mean separation.

Table 3. Effect of carbon dioxide concentration on growth and biomass partitioning of Scutellaria lateriflora at 35 and $49 \mathrm{~d}$ after planting.

\begin{tabular}{|c|c|c|c|c|c|c|c|}
\hline $\begin{array}{l}\mathrm{CO}_{2} \\
\left(\mu \mathrm{mol} \cdot \mathrm{mol}^{-1)}\right.\end{array}$ & $\begin{array}{l}\text { Plant } \\
\text { ht }(\mathrm{cm})\end{array}$ & $\begin{array}{l}\text { Nodes } \\
\text { (no.) }\end{array}$ & $\begin{array}{l}\text { Leaf area } \\
\qquad\left(\mathrm{cm}^{2}\right)\end{array}$ & $\begin{array}{l}\text { Stem dry } \\
\text { wt }(g)\end{array}$ & $\begin{array}{l}\text { Leaf dry } \\
\text { wt (g) }\end{array}$ & $\begin{array}{l}\text { Total dry } \\
\text { wt }(g)\end{array}$ & $\begin{array}{c}\text { Leaf mass } \\
\text { per area }\left(\mathrm{kg} \cdot \mathrm{m}^{-2}\right)\end{array}$ \\
\hline & \multicolumn{7}{|c|}{$35 \mathrm{~d}$ after planting } \\
\hline 400 & $13.1 \mathrm{a}^{\mathrm{z}}$ & $7.0 \mathrm{a}$ & $169 \mathrm{a}$ & $0.152 \mathrm{a}$ & $0.456 \mathrm{a}$ & $0.608 \mathrm{a}$ & $0.028 \mathrm{a}$ \\
\hline \multirow[t]{2}{*}{3000} & $18.4 \mathrm{~b}$ & $7.5 \mathrm{a}$ & $235 \mathrm{~b}$ & $0.275 \mathrm{c}$ & $0.720 \mathrm{c}$ & $0.995 \mathrm{c}$ & $0.030 \mathrm{~b}$ \\
\hline & \multicolumn{7}{|c|}{$49 \mathrm{~d}$ after planting } \\
\hline 400 & $26.0 \mathrm{a}$ & $10.6 \mathrm{a}$ & $641 \mathrm{a}$ & $1.27 \mathrm{a}$ & $2.74 \mathrm{a}$ & $4.01 \mathrm{a}$ & $0.034 \mathrm{a}$ \\
\hline 3000 & $30.8 \mathrm{a}$ & $11.3 \mathrm{a}$ & $729 \mathrm{~b}$ & $2.42 \mathrm{~b}$ & $3.81 \mathrm{~b}$ & $6.23 \mathrm{~b}$ & $0.040 \mathrm{~b}$ \\
\hline
\end{tabular}

${ }^{\mathrm{z}}$ Mean separation within columns within columns and species at $P \leq 0.05$ using Tukey's mean separation.

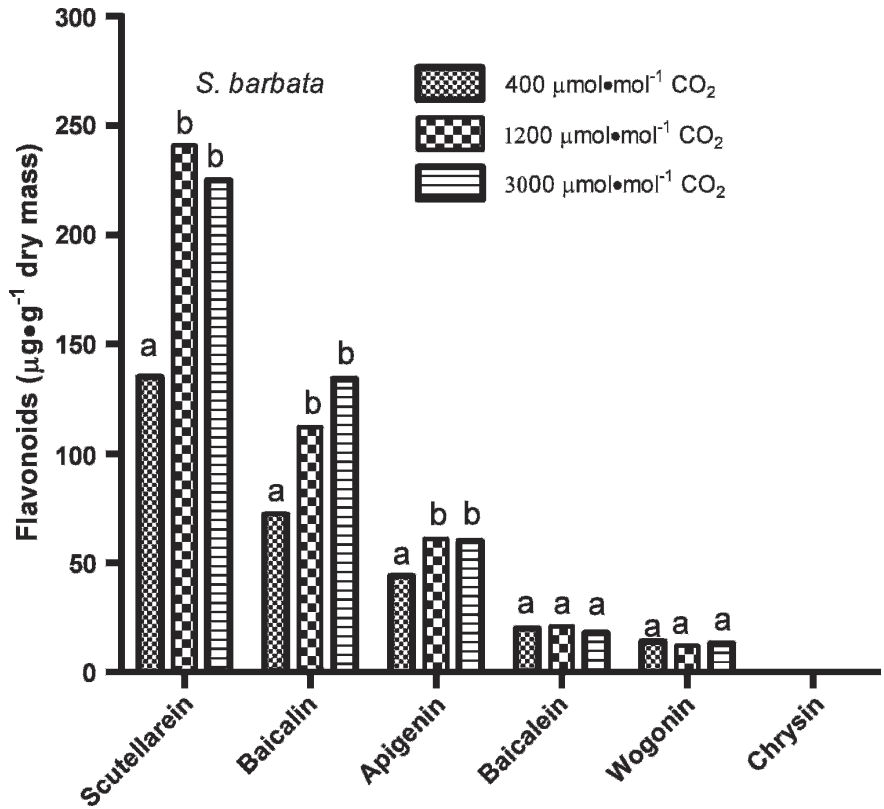

Fig. 5. Effect of 400, 1200, and $3000 \mu \mathrm{mol} \cdot \mathrm{mol}^{-1} \mathrm{CO}_{2}$ on the concentration of bioactive flavonoids in shoot tissue of Scutellaria barbata at $49 \mathrm{~d}$ after planting. Treatments with the different letter for a specific flavonoid are statistically different at $P \leq 0.05$.

$1200 \mu \mathrm{mol} \cdot \mathrm{mol}^{-1} \mathrm{CO}_{2}$, and a 13.7 -fold increase at 3000 $\mu \mathrm{mol} \cdot \mathrm{mol}^{-1} \mathrm{CO}_{2}$ (Fig. 8). Overall, there was at least a 10 -fold increase in the total production of flavonoid per plant at $3000 \mu \mathrm{mol} \cdot \mathrm{mol}^{-1} \mathrm{CO}_{2}$ over ambient $\left(400 \mu \mathrm{mol} \cdot \mathrm{mol}^{-1}\right)$ conditions, with the average total of flavonoids analyzed increasing from $3.3 \mathrm{mg} / \mathrm{plant}$ at $400 \mu \mathrm{mol} \cdot \mathrm{mol}^{-1} \mathrm{CO}_{2}$ to $14.0 \mathrm{mg} / \mathrm{plant}$ at 1200 $\mu \mathrm{mol} \cdot \mathrm{mol}^{-1} \mathrm{CO}_{2}$ and $45.5 \mathrm{mg} / \mathrm{plant}$ at $3000 \mu \mathrm{mol} \cdot \mathrm{mol}^{-1} \mathrm{CO}_{2}$.

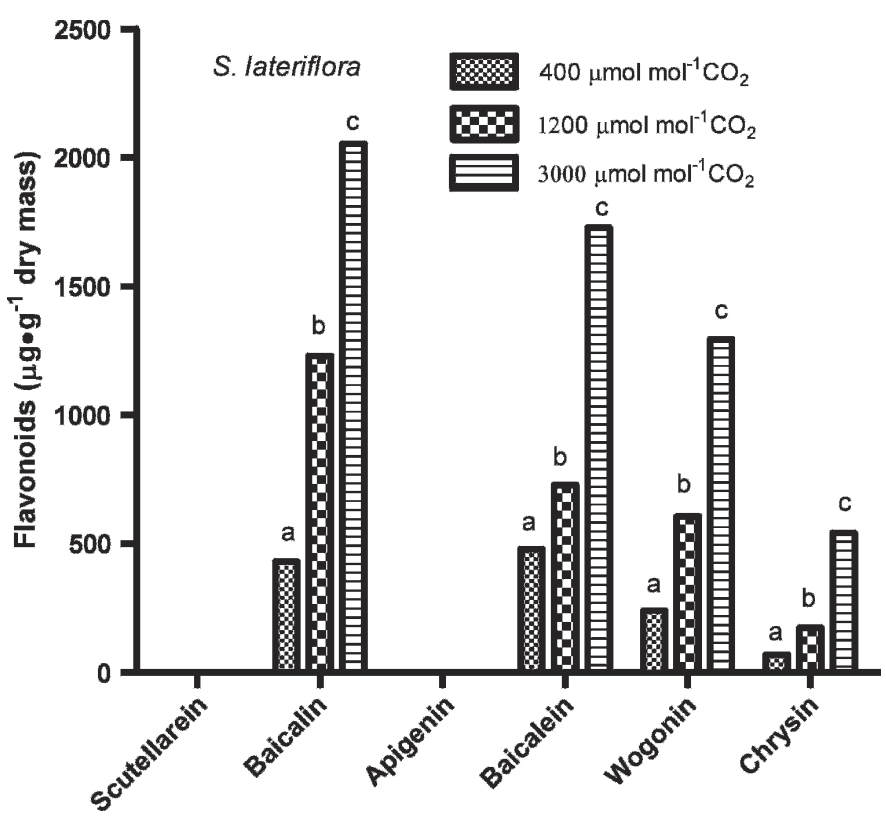

Fig. 6. Effect of 400, 1200, and $3000 \mu \mathrm{mol} \cdot \mathrm{mol}^{-1} \mathrm{CO}_{2}$ concentration on the concentration of bioactive flavonoids in shoot tissue of Scutellaria lateriflora at $49 \mathrm{~d}$ after planting. Treatments with the different letter for a specific flavonoid are statistically different at $P \leq 0.05$.

\section{Discussion}

There is a critical need to develop the technology to produce a consistent supply of high-quality pharmaceutically important plants. CE are one means of producing these high-value plants under conditions necessary to meet current and future regulatory standards for quality control. CE provide the technology to 


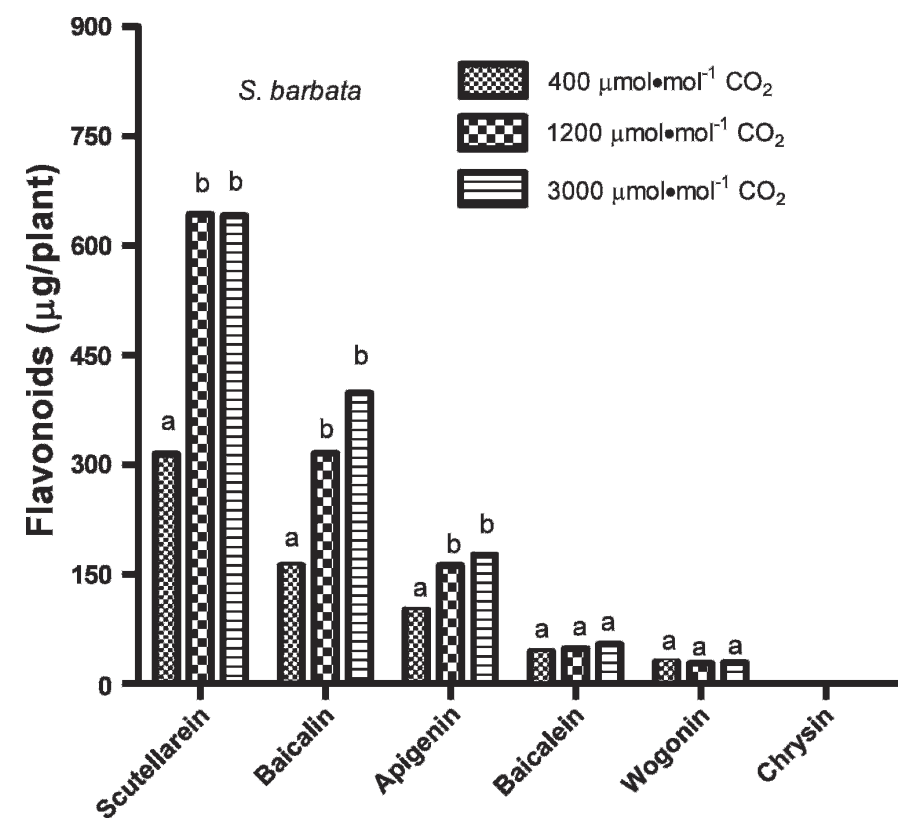

Fig. 7. Effect of 400, 1200, and $3000 \mu \mathrm{mol} \cdot \mathrm{mol}^{-1} \mathrm{CO}_{2}$ concentration on the total plant content of bioactive flavonoids in shoot tissue of Scutellaria barbata at $49 \mathrm{~d}$ after planting. Treatments with the different letter for a specific flavonoid are statistically different at $P \leq 0.05$.

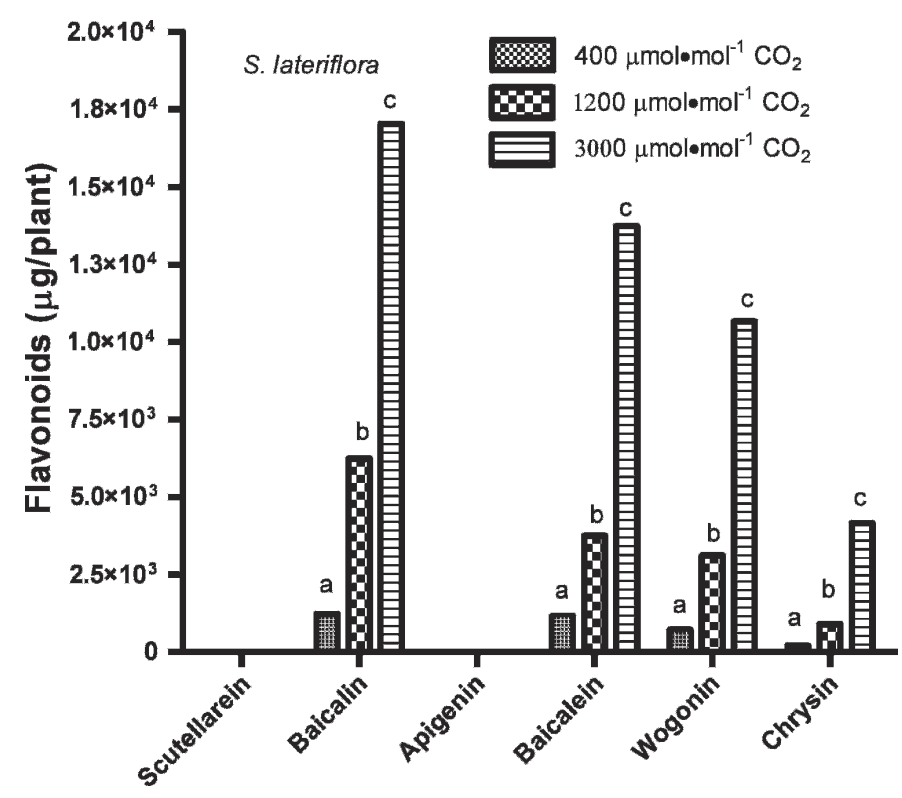

Fig. 8. Effect of 400, 1200, and $3000 \mu \mathrm{mol} \cdot \mathrm{mol}^{-1} \mathrm{CO}_{2}$ concentration on the total plant content of bioactive flavonoids in shoot tissue of Scutellaria lateriflora at $49 \mathrm{~d}$ after planting. Treatments with the different letter for a specific flavonoid are statistically different at $P \leq 0.05$.

optimize biomass and biopharmaceutical content with environmental modification. CE also allow multiple harvests to occur, significantly increasing the total yield per area per year.

In well-managed field systems, the nutrient, irrigation, and pest management regime can be optimized for plant production. Under field conditions, however, the ambient concentration of $\mathrm{CO}_{2}\left(<400 \mu \mathrm{mol} \cdot \mathrm{mol}^{-1}\right)$ is well below typical the $\mathrm{CO}_{2}$ saturation point of $1000-1200 \mu \mathrm{mol} \cdot \mathrm{mol}^{-1}$ for photosynthesis in C3 plants and is a primary factor limiting biomass production.
Scutellaria barbata and S. lateriflora responded to $\mathrm{CO}_{2}$ enrichment by accelerating the growth rate, producing more biomass, and decreasing the time to flowering when the $\mathrm{CO}_{2}$ concentration was increased from 400 to $1200 \mu \mathrm{mol} \cdot \mathrm{mol}^{-1} \mathrm{CO}_{2}$.

The response of these Scutellaria species is consistent with the responses reported for numerous food and ornamental crops over the years (Porter and Grodzinski, 1985; Stutte, 2006; Wheeler et al., 2003). These growth effects are generally associated with increased rate of leaf photosynthesis when $\mathrm{CO}_{2}$ ceases to be a limiting factor for carbon assimilation.

Under ambient $\mathrm{CO}_{2}$ conditions, the total concentration of baicalein, baicalin, and wogonin from field-grown (D. Shannon, personal communication), aseptically produced (Cole et al., 2008), and CE production plants were comparable (1.7, 1.0, and $1.2 \mathrm{mg} \cdot \mathrm{g}^{-1} \mathrm{DM}$, respectively) despite significant differences in plant age and cultural conditions. Although the total concentration of the three compounds was comparable, there is significant variation in the relative concentrations of compounds from the different production systems. Field-grown plants contained $\approx 1.5 \mathrm{mg} \cdot \mathrm{g}^{-1} \mathrm{DM}$ baicalin, $\approx 0.2 \mathrm{mg} \cdot \mathrm{g}^{-1} \mathrm{DM}$ baicalein, and trace amounts of wogonin (D. Shannon, personal communication). Cole et al. (2008) reported values of $0.6 \mathrm{mg} \cdot \mathrm{g}^{-1} \mathrm{DM}$ baicalein, $0.2 \mathrm{mg} \cdot \mathrm{g}^{-1} \mathrm{DM}$ baicalin, and $0.2 \mathrm{mg} \cdot \mathrm{g}^{-1} \mathrm{DM}$ wogonin from aseptic culture of $S$. lateriflora. These contrasted with our results of $\approx 0.5 \mathrm{mg} \cdot \mathrm{g}^{-1}$ for baicalin and baicalin, and $\approx 0.25 \mathrm{mg} \cdot \mathrm{g}^{-1} \mathrm{DM}$ for wogonin in CE plants.

The relative agreement of the total concentration, but differences in relative percentages, of baicalin, bacalein, and wogonin under ambient $\mathrm{CO}_{2}$ conditions suggests that carbon flow into the flavonoid pathway are comparable, but that the regulation of the flavonoid pathway is affected by other environmental or genetic factors.

The increase in growth associated with $\mathrm{CO}_{2}$ enrichment in $\mathrm{CE}$ was also accompanied by an increase in the total content of flavonoids in the vegetative tissue of $S$. barbata and $S$. lateriflora. However, the response of flavonoid biosynthesis to $\mathrm{CO}_{2}$ enrichment was not the same in both species. An example is provided from the analysis of baicalin and baicalein, two flavonoids that were detected in both species. In $S$. lateriflora, the concentration of baicalin and baicalein was nearly identical at ambient $\left(400 \mu \mathrm{mol} \cdot \mathrm{mol}^{-1} \mathrm{CO}_{2}\right)$ conditions, and they were the dominant flavonoids. In contrast, the concentration of baicalin was three to four times higher than its aglycone, baicalein, in $S$. barbata, although the concentrations were much lower than $S$. lateriflora. In $S$. lateriflora, four compounds were detected: baicalin and its glycone, baicalin, and chrysin and its methoxylated structure wogonin. All four compounds increased significantly in response to elevated $\mathrm{CO}_{2}$. Although flavone concentrations were lower in $S$. barbata, there was discrimination in the response of the flavones to $\mathrm{CO}_{2}$ that was not apparent with $S$. lateriflora. Unlike $S$. lateriflora, there was a significant increase in the baicalin/ baicalein ratio with increasing $\mathrm{CO}_{2}$, rising from 3.8 at 400 $\mu \mathrm{mol} \cdot \mathrm{mol}^{-1} \mathrm{CO}_{2}$ to 7.44 at $3000 \mu \mathrm{mol} \cdot \mathrm{mol}^{-1} \mathrm{CO}_{2}$. There was a two times increase in the concentration of scutellarein with $\mathrm{CO}_{2}$ enrichment, but only a modest $35 \%$ or no significant increase in the concentration of the aglycones apigenin, baicalein, and wogonin.

These results are generally consistent with those of $\mathrm{B}$. Schmidt, W.D. Clark, and S.B Idso (unpublished data) who grew $S$. baicalensis at $700 \mu \mathrm{mol} \cdot \mathrm{mol}^{-1} \mathrm{CO}_{2}$ to determine what 
effects rising levels of atmospheric $\mathrm{CO}_{2}$ might have on the production of active constituents in medicinal plants. They found, as expected, that total dry biomass was increased significantly, and that flowering was advanced by 1 week. That is consistent with the results observed with $S$. barbata and $S$. lateriflora. They also found that the overall antioxidant capacity, based on the ferric reducing antioxidant power assay, was increased. They did not see a consistent response of bioactive constituents to $\mathrm{CO}_{2}$ enrichment, with wogonin and baicalin increasing in concentration and that of baicalein decreasing.

Scutellarein was not detected in S. lateriflora, but was the predominant flavonoid in S. barbata, followed by baicalin, apigenin, baicalein, and wogonin. Increasing the $\mathrm{CO}_{2}$ from 400 to $1200 \mu \mathrm{mol} \cdot \mathrm{mol}^{-1}$ resulted in a $78 \%$ increase in scutellarein, a $55 \%$ increase in baicalin, and a 39\% increase in apigenin, but had no effect on baicalein or wogonin concentrations. That lack of a change in baicalein concentration may be due to increased turnover to baicalin, leaving a steady-state level of baicalein. $\mathrm{CO}_{2}$ enrichment may have also activated a glucosyl-transferase responsible for the glucosylation of baicalein, resulting in an increase in levels of baicalin. Similarly, wogonin has a methoxy group at $\mathrm{C}-8$ on ring $\mathrm{A}$ and it may be that enzymes responsible for methoxylation are not activated with increased $\mathrm{CO}_{2}$ enrichment. However, it appears that the hydroxylases were activated with elevated $\mathrm{CO}_{2}$, resulting in increased levels of scutellarein, baicalin, and apigenin in the shoot tissue.

As with $S$. barbata, baicalin and baicalein concentration increased in the leaf and stem tissue of $S$. lateriflora with increasing $\mathrm{CO}_{2}$ concentration, although baicalin had greater increases than baicalein, thus shifting the ratio between the compounds. This is pharmacologically significant because Lai et al. (2003) found that orally administered baicalin was absorbed more slowly and to a lesser extent than baicalein in rats.

Wogonin metabolism was also different in response to $\mathrm{CO}_{2}$ enrichment between the species. As with baicalin and baicalein, the concentration of wogonin was much higher $(17 \times)$ in $S$. lateriflora than in $S$. barbata. $\mathrm{CO}_{2}$ enrichment had no effect on wogonin concentration in $S$. barbata, but had dramatic effects in $S$. lateriflora with concentration increasing five times from ambient to $3000 \mu \mathrm{mol} \cdot \mathrm{mol}^{-1} \mathrm{CO}_{2}$.

The magnitude of the $\mathrm{CO}_{2}$ response of species specific flavonoids were also variable. Scutellarein and apigenin were detected only in $S$. barbata, but not S. lateriflora, and the concentration increased [scutellarein (78\%) and apigenin $(55 \%)$ ] when $\mathrm{CO}_{2}$ was increased to $1200 \mu \mathrm{mol} \cdot \mathrm{mol}^{-1}$, but there was no statistically significant response to additional enrichment to $3000 \mu \mathrm{mol} \cdot \mathrm{mol}^{-1}$. Chrysin was only detected in $S$. lateriflora, and was the least abundant flavonoid detected, but did show a strong response to $\mathrm{CO}_{2}$, and increased over 7-fold over ambient in the $3000 \mu \mathrm{mol} \cdot \mathrm{mol}^{-1} \mathrm{CO}_{2}$ treatment.

There are clearly species-specific responses to flavonoid composition, content, and response to $\mathrm{CO}_{2}$. There is currently not a good chemical or biosynthetic explanation for this because both show similar flavonoids, except to suggest that the biosynthetic machinery in $S$. lateriflora is activated by $\mathrm{CO}_{2}$ enrichment.

The effects of $\mathrm{CO}_{2}$ concentration on apigenin and scutellarein concentration is interesting because both compounds have a hydroxyl group at C-4' on ring B. It is generally known that the $\mathrm{B}$ ring of flavonoids is derived from the phenylpropanoid pathway and it may be that in the leaves, the conversion of cinnamic acid to coumaric acid was inactivated or that coumaric acid was shunted to another pathway, making this C6-C3 precursor unavailable for the synthesis of apigenin and scutellarein. Additional work is required to test this hypothesis.

These results clearly demonstrate the potential to use CE to increase the production and quality of Scutellaria species. This is a significant finding because the practice has the potential to increase the value of the product by reducing the time to harvest, increasing yield per unit area, and increasing bioactivity per gram DM. Taken together, the increase in yield and quality provides an economic incentive to produce a consistent pharmaceutical-grade product for commerce. The impacts of cultural conditions and $\mathrm{CO}_{2}$ concentration on biopharmaceutical production has not been widely investigated and needs to be understood, especially when the objective is the optimization of the plant chemistry.

These results also indicate that although the total content of bioactive flavonoids can be increased using $\mathrm{CO}_{2}$ enrichment, the composition of flavonoids is also affected. There are indications that the composition would affect bioavailability and bioactivity of the a.i. (Lai et al., 2003). This suggests that not only the total content, but also the composition of flavonoids, will have to be considered in the development of any $\mathrm{CE}$ production system for medicinal plants.

\section{Literature Cited}

Awad, R., J.T. Arnason, V. Trudeau, C. Bergeron, J.W. Budziinski, B.C. Foster, and Z. Merali. 2003. Phytochemical and biological analysis of skullcap (Scutellaria lateriflora L.): A medicinal plant with anxiolytic properties. Phytomedicine 10:640-649.

Bonham, M., J. Posakony, L. Coleman, B. Montgomery, J. Simon, and P.S. Nelson. 2005. Characterization of chemical constituents in Scutellaria baicalensis with antiondrogenic and growth-inhibitory activities towards prostrate carcinoma. Clin. Cancer Res. 11:39053914.

Charron, C.S. and C.E. Sams. 2004. Glucosinolate content and myrosinase activity in rapid-cycling Brassica oleracea grown in a controlled environment. J. Amer. Soc. Hort. Sci. 129:321-330.

Cole, I.B., J. Cao, A.R. Alan, P.K. Saxena, and S.J. Murch. 2008. Comparisons of Scutellaria baicalensis, Scutellaria lateriflora and Scutellaria ramemosa: Genome size, antioxidant potential and phytochemistry. Planta Med. 74:474-481.

Cole, I.B., P.K. Sacena, and S.J. Murch. 2007. Medicinal biotechnology in the genus scutellaria. In Vitro Cell. Dev. Biol. Plant 43:318327.

Eraso, I., G.W. Stutte, and E.C. Stryjewski. 2003. Chronic exposure to ethylene induces stress symptoms in radish, p. 94-99. In: M Vendrell, H. Klee, J.C. Pech. and F. Romojaro (eds.). Proceedings of the NATO advanced research workshop on biology and biotechnology of the plant hormone ethylene. ISO Press, Amsterdam, The Netherlands.

Estiarte, M., J. Peñuelas, B.A. Kimball, D.L. Hendrix, P.J. Pinter, Jr., G.W. Wall, R.L. LaMonte, and D.J. Hunsaker. 1999. Free-air $\mathrm{CO}_{2}$ enrichment of wheat: Leaf flavonoid concentration throughout the growth cycle. Physiol. Plant. 105:423-433.

Furbee, R.B., K.S. Barlotta, M.K. Allen, and C.P. Holstege. 2006. Hepatotoxicity associated with herbal products. Clin. Lab. Med. 26:227-241.

Goins, G.D., N.C. Yorio, G.W. Stutte, R.M. Wheeler, and J.C. Sager. 2003. Baseline environmental testing of candidate salad crops with horticultural approaches and constrains typical of spaceflight. Soc. Automotive Eng. Tech. Paper 2003-01-2481.

Greenfield, J. and J. Davis. 2004. Medicinal herb production guide: Skullcap (Scutellaria lateriflora L.). 2 Apr. 2008. <http://www.natur almedicinesofnc.org/Growers\%20Guides/Skullcap-gg.pdf>. 
Gruda, N. 2005. Impact of environmental factors on product quality of greenhouse vegetables for fresh consumption. Crit. Rev. Plant Sci. 24:227-247.

Hinkleton, P.R. 1988. $\mathrm{CO}_{2}$ enrichment in the greenhouse. Timber Press Growers Handbook 2. Timber Press, Portland, OR.

Hoagland, D.R. and D.I. Arnon. 1950. The water culture method for growing plants without soil. California Agr. Expt. Sta. Circ. 347.

Janke, R., J. DeArmond, and D. Coltrain. 2005. Farming a few acres of herbs: An herb growers handbook. Kansas State Univ. Publ. S-144.

Joshee, N., T.S. Patrick, R.S. Mentreddy, and A.K. Yadav. 2002. Skullcap: Potential medicinal crop, p. 58-586. In: J. Janick and A. Whipkey (eds.). Trends in new crops and new uses. ASHS Press, Alexandria, VA.

Lai, M.Y., S.L. Hsiu, S.Y. Tsai, Y.C. Hou, and P.D.L. Chao. 2003. Comparison of metabolic pharmacokinetics of baicalin and baicalein in rats. J. Pharm. Pharmocol. 55:205-209.

Malikov, V.M. and M.P. Yuldashev. 2002. Phenolic compounds of plants of the Scutellaria L. genus: Distribution, structure and properties. Chem. Nat. Compd. 38:358-406.

Mars, C. and S. Bent. 1999. An evidence-based review of the 10 most commonly used herbs. West. J. Med. 171:168-171.

Molony, D. and M.M.P. Molony. 1998. The American Association of Oriental Medicines complete guide to Chinese herbal medicine. Berkley Publishing Group, New York.

Pagliarulo, C.L., A.L. Hayden, and G.A. Giacomelli. 2003. Potential for greenhouse aeroponic cultivation of Uritica dioca. Acta Hort. 659:61-66.

Porter, B. 2005. Skullcap production in Saskatchewan. 2 Apr. 2008. $<$ http://www.agriculture.gov.sk.ca/Default.aspx?DN=a6cd8eb3e7fd-4b57-9d21-5d83a74c75bf>.

Porter, M.S. and B. Grodzinski. 1985. $\mathrm{CO}_{2}$ enrichment of protected crops. Hort. Rev. (Amer. Soc. Hort. Sci.) 7:345-398.

Radovich, T.J.K., M.D. Kleinhenz, J.G. Streeter, A.R. Miller, and J.C. Scheerens. 2005. Planting date affects total glucosinolate concentrations in six commercial cabbage cultivars. HortScience 40:106-110.

Richards, J.T., N.C. Yorio, S.L. Edney, C.E. Yunker, and G.W. Stutte. 2004. Evaluating growth characteristics and total anthocyanin content in three cultivars of red romaine-type lettuce (Lactus sativa L.) in response to three lighting intensities. Proc. Plant Growth Regul. Soc. Amer. 31:110-114.

Rosen, C.J., V.A. Fritz, G.M. Gardner, S.S. Hecht, S.G. Carmella, and P.M. Kenney. 2005. Cabbage yield and glucosinolate concentrations as affected by nitrogen and sulfur fertility. HortScience 40:14931498

Sato, Y., S. Suzaki, T. Nishikawa, M. Kihara, H. Shibata, and T. Higuti. 2000. Phytochemical flavones isolated from Scutellaria barbata and antibacterial activity against methicillin-resistant Staphylococcus aureus. J. Ethnopharmocol. 72:483-488.
Smolinski, S.C. 2005. Herbal product contamination and toxicity. J. Pharm. Pract. 18:188-208.

Stutte, G.W. 1999. Phytochemicals: Implications for long duration space missions, p. 275-286. In: H.G. Cutler and S.J. Cutler (eds.). Biologically active natural products: Agrochemicals. CRC Press, Boca Raton, FL.

Stutte, G.W. 2006. Process and product: Recirculating hydroponics and bioactive compounds in a controlled environment. HortScience 41:526-530.

Stutte, G.W., I. Eraso, S. Anderson, and R.D. Hickey. 2006. Bioactivity of volatile alcohols on the germination and growth of Raphanus sativus L. seedlings. HortScience 41:108 112

Stutte, G.W., I. Eraso, and K.B. Downing. 2007. Feasibility of controlled environment production of Scutellaria species. Acta Hort. 756:213-219

Stutte, G.W., P.A. Fowler, I. Eraso, and L.L. Koss. 2005. Volatile organic compound analysis (VOCA): A system for evaluating atmospheric contaminants on plant growth. Soc. Automotive Eng. Tech. Paper 2005-01-2771.

Thomas, A.L. and D. Schrock. 2004. Performance of 67 native midwestern U.S. perennials in a low-maintenance landscape. HortTechnology 14:381-388.

U.S. Department of Agriculture. 2008. The PLANTS database. 2 Apr. 2008. <http://plants.usda.gov>.

Veteli, T.O., K. Kuokkaneh, R. Julkunen-Titto, H. Roininen, and J. Tahvanainen. 2002. Effects of elevated $\mathrm{CO}_{2}$ and temperature on plant growth and herbivore defensive chemistry. Glob. Change Biol. $8: 1240-1252$

Wang, S.Y., J.A. Bunce, and J.L. Maas. 2003. Elevated carbon dioxide increases contents of antioxidant compounds in field-grown strawberries. J. Agr. Food Chem. 51:4315-4320.

Wheeler, R.M., J.C. Sager, R.P. Prince, W.M. Knott, C.L. Mackowiak, G.W. Stutte, N.C. Yorio, L.M. Ruffe, B.V. Peterson, G.D. Goins, C.R. Hinkle, and W.L. Berry. 2003. Crop production for advanced life support systems: Observations from the Kennedy Space Center Breadboard Project. National Aeronautics and Space Administration Tech. Memo. 2003-211184.

Wills, R.B.H. and D.L. Stuart. 2004. Generation of high quality Australian skullcap products. Rural Ind. Res. Dev. Corp. Publ. No. 04/020.

Wolsko, P.M., D.K. Solondz, R.S. Phillips, S.C. Schachter, and D.M. Eisenburg. 2005. Lack of herbal supplement characterization in published randomized controlled trials. Amer. J. Med. 118:10871093.

Yin, X., J. Zhou, C. Jie, D. Xing, and Y. Zhang. 2004. Anticancer activity and mechanism of Scutellaria barbata extract on human lung cancer cell line A549. Life Sci. 75:2233-2244. 